\title{
First record of Arctodiaptomus wierzejskii (Richard, 1888) (Copepoda Calanoida Diaptomidae) from Malta
}

\author{
Luca Montevago, Luca Vecchioni, Federico Marrone*
}

\begin{abstract}
Diaptomid copepods belonging to the genus Arctodiaptomus Kiefer, 1932 were collected in two temporary water bodies in Malta. The morphological identification of the collected specimens proved that they belong to Arctodiaptomus wierzejskii (Richard, 1888) even if a morphological peculiarity pertaining to the morphology of the male right antennule of the Maltese populations was observed and here briefly discussed. This finding constitutes the first record of a calanoid copepod from the inland waters of the Maltese Islands.
\end{abstract}

Key words: Maltese inland waters, microcrustaceans, temporary waters.

Riassunto - Prima segnalazione di Arctodiaptomus wierzejskii (Richard, 1888) (Copepoda Calanoida Diaptomidae) da Malta.

Copepodi diaptomidi appartenenti al genere Arctodiaptomus Kiefer, 1932 sono stati raccolti in due corpi d'acqua temporanei a Malta. L'identificazione morfologica degli esemplari raccolti ha consentito di attribuirli alla specie Arctodiaptomus wierzejskii (Richard, 1888) anche se da questa si differenziano per una particolarità morfologica relativa alla morfologia delle antennule maschili destre, qui brevemente discussa. Questo rinvenimento è il primo di un copepode calanoide per le acque interne delle isole maltesi.

Parole chiave: acque interne maltesi, acque temporanee, microcrostacei.

\section{INTRODUCTION}

The Maltese Archipelago is formed by three main islands (Malta, Gozo and Comino) and a number of minor islets and small rocks mainly composed of Oligo-Miocene limestones. It is located at the centre of the Mediterranean basin, $96 \mathrm{~km}$ south of the Sicilian coast. Overall, the archipelago presents a surface area of about $315 \mathrm{~km}^{2}$,

Department of Biological, Chemical and Pharmaceutical Sciences and Technologies (STEBICEF), University of Palermo, Italy.

E-mail: luca-lm@live.it; luca.vecchioni@unipa.it

* Corresponding author: federico.marrone@unipa.it

(C) 2020 Luca Montevago, Luca Vecchioni, Federico Marrone

Received: 24 September 2020

Accepted for publication: 30 September 2020

Online publication: 18 November 2020 with Malta, the largest island, covering an area of about $246 \mathrm{~km} 2$. The climate is typically Mediterranean, with a wet season in which about $85 \%$ of the total annual rainfall occurs, and a dry period lasting roughly from April to September. The average annual precipitation is about $530 \mathrm{~mm}$ and the average temperature is $18.6^{\circ} \mathrm{C}$ (Schembri, 1993).

To date, the available data on Maltese non-marine crustaceans focused on Branchiopoda (Lanfranco et al., 1991; Lanfranco, 2001; Korn et al., 2006; Lukić et al., 2019; Marrone \& Vecchioni, 2020) and malacostracans (e.g. Vecchioni et al., 2017, 2019; Deidun et al., 2018; Hupało et al., 2019), whereas only scarce data are to date available on Copepoda and Ostracoda (e.g. Baldacchino, 1983). In particular, no inland water calanoid copepods have ever been reported from the archipelago.

In the frame of a wide survey aimed at exploring the inland water copepod fauna of the Central Mediterranean area, some calanoid copepods were collected in Malta whose identity and morphology are hereby discussed.

\section{MATERIALS AND METHODS}

Crustacean samples were collected in Malta on $31^{\text {st }}$ January 2008 in a "rock-pool" located in Wied Es-Sabtah (site MT001, WGS84 geographical coordinates: $35.836060 \mathrm{~N}, 14.514882 \mathrm{E} ; 44 \mathrm{~m}$ a.s.1.) and in a concrete reservoir near Sigggiewi (site MT002, WGS84 geographical coordinates: $35.847023 \mathrm{~N}, 14.434342 \mathrm{E} ; 108 \mathrm{~m}$ a.s.1.) (Fig. 1). Sampling was carried out with a $200 \mu \mathrm{m}$ mesh hand net. The collected specimens were fixed in situ using $90 \%$ ethanol and sorted out in laboratory under a stereomicroscope.

Collected calanoid copepod specimens were identified according to Kiefer (1978) and Ranga-Reddy (1994). Further comparisons were made with the drawings reported in Gurney (1931), Damian-Georgescu (1966), Petkovski (1983), Stella (1984), and Einsle (1993). Moreover, Tunisian specimens of Arctodiaptomus wierzejskii (Richard, 1888) from Sidi Othman and El Hisiane (sites F109 and F193 in Marrone et al., 2016) were included as comparative material. Drawings were made with a microscope equipped with a camera lucida. 


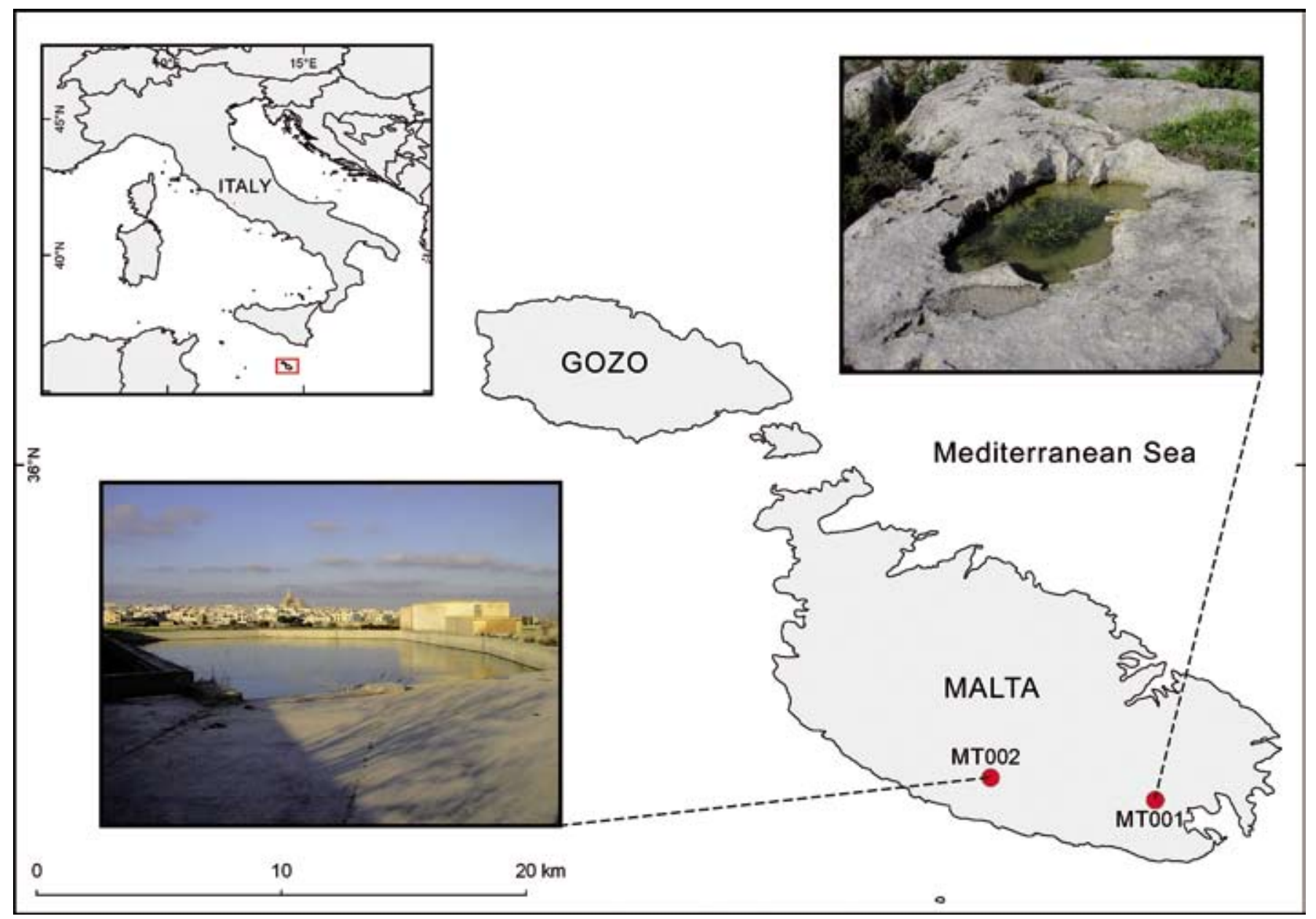

Fig. 1 - Location of the Maltese occurrence localities of Arctodiaptomus wierzejskii: rock pool in Wied Es-Sabtah (MT001) and concrete reservoir near Sigggiewi (MT002). / Località maltesi di Arctodiaptomus wierzejskii: pozza in roccia a Wied Es-Sabtah (MT001) e vasca di cemento presso Sig̈giewi (MT002).

Co-occurring branchiopod and ostracod taxa were identified according to Alonso (1996) and Meisch (2000), respectively. Samples of Maltese and Tunisian A. wierzejskii, and co-occurring crustacean taxa, are kept in FM collections at the University of Palermo and are available for loan on request. Moreover, 10 males and 10 females from MT002 were deposited in the collection of the Zoology Section "La Specola", Natural History Museum, University of Florence (Italy) under the collection number MZUF 661.

\section{RESULTS}

At the sampling date, the electric conductivity values were $199 \mu \mathrm{S} \mathrm{cm}-1$ (20 $\left.{ }^{\circ} \mathrm{C}\right)$ in MT001 and $688 \mu \mathrm{S} \mathrm{cm}$ $\left(17^{\circ} \mathrm{C}\right)$ in MT002. The co-occurring crustacean fauna (Tab. 1) is richer in MT001, including the species typically found in temporary rock pools, whereas that occurring in MT002 only includes the euryecious daphniid Daphnia magna (see also Marrone \& Vecchioni, 2020). Unexpectedly, no cyclopoid copepods were collected in the two sites.
The morphology of the collected diaptomid copepods allowed us to identify them as Arctodiaptomus wierzejskii, although the Maltese specimens slightly differ from the standard morphology of the species in a detail related to male right antennule (see below).

The antennules (A1) of females are symmetrical and consist of 25 segments, with the typical chaetotaxy of the species as described in Kiefer (1978). The right male antennule is modified and geniculated in the fourth last segments. The thirteenth segment of the right antennule has a robust and well-developed spine, while in its antepenultimate segment there is a spiny comb-shaped process (Fig. 2A). When compared with the available drawings of $A$. wierzejskii and with $A$. wierzejskii individuals from Tunisia, the Maltese specimens present a morphological peculiarity. In Tunisian male specimens, the $14^{\text {th }}$ segment of the right antennule has a short but stout tooth. This feature is constantly represented in all the available drawings of the species. Conversely, in the Maltese individuals the tooth on the $14^{\text {th }}$ segment is normally absent (Fig. 3). Only in one out of the 35 studied Maltese males the spine is present, although poorly developed (Fig. $3 \mathrm{H}$ ). 
Tab. 1 - Crustacean assemblages recorded in the two study sites on January $31^{\text {th }} 2008$. / Popolamenti a crostacei osservati nei due siti di studio il 31 gennaio 2008.

* Ceriodaphnia quadrangula Müller, 1785 sensu Alonso (1996).

\section{TAXA}

Branchiopoda

Anostraca

Branchipus schaefferi Fischer, 1834

Spinicaudata

Cyzicus tetracerus (Krynicki,1830)

Anomopoda

Daphnia (Ctenodaphnia) magna Straus, 1820

Ceriodaphnia sp.*

Coronatella (Ephemeralona) elegans (Kurz, 1875)

Ostracoda

\section{Podocopa}

Plesiocypridopsis newtoni (Brady \& Robertson, 1870)

Potamocypris arcuata (Sars, 1903)

\section{Copepoda}

\section{Calanoida}

Arctodiaptomus wierzejskii (Richard, 1888)

\begin{tabular}{|l|c|}
\hline MT001 & MT002 \\
$X$ & \\
$X$ & \\
& \\
$X$ & $X$ \\
$X$ & \\
& \\
$X$ & \\
$X$ & \\
$X$ & \\
\hline
\end{tabular}

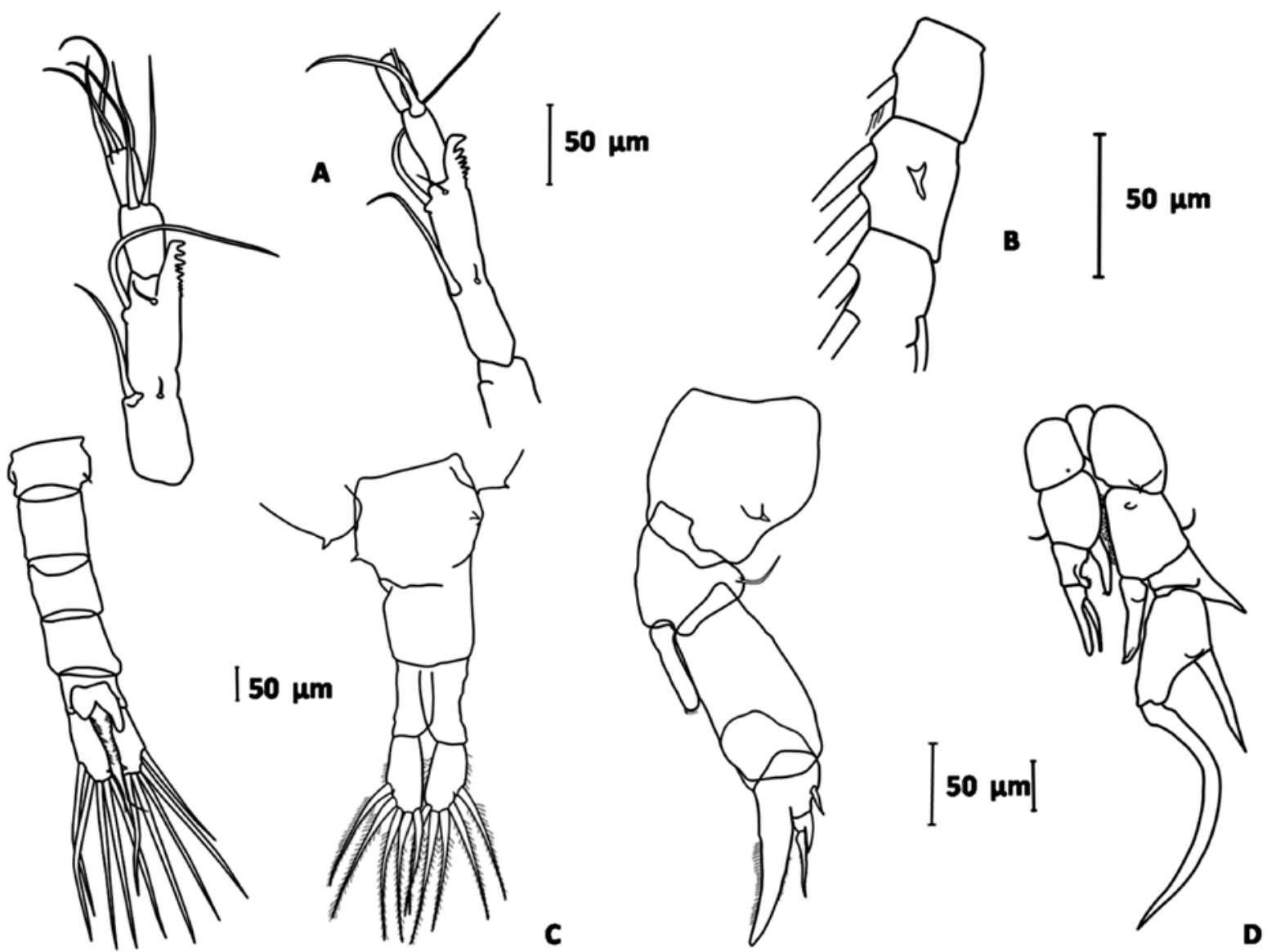

Fig. 2 - Morphological details of $A$. wierzejskii individuals from Malta. A) detail of the male right antennule. The comb-shaped process is evident; B) detail of the second endopodite segment of male P2; C) male (left) and female (right) urosomes; D) female (left) and male (right) P5. / Dettagli morfologici di individui maltesi di $A$. wierzejskii. A) particolare delle antennule destre maschili. Il processo a forma di pettine è evidente; B) particolare del secondo segmento dell'endopodite del P2 maschile; C) urosoma maschile (a sinistra) e femminile (a destra); D) P5 femminile (a sinistra) e maschile (a destra). 

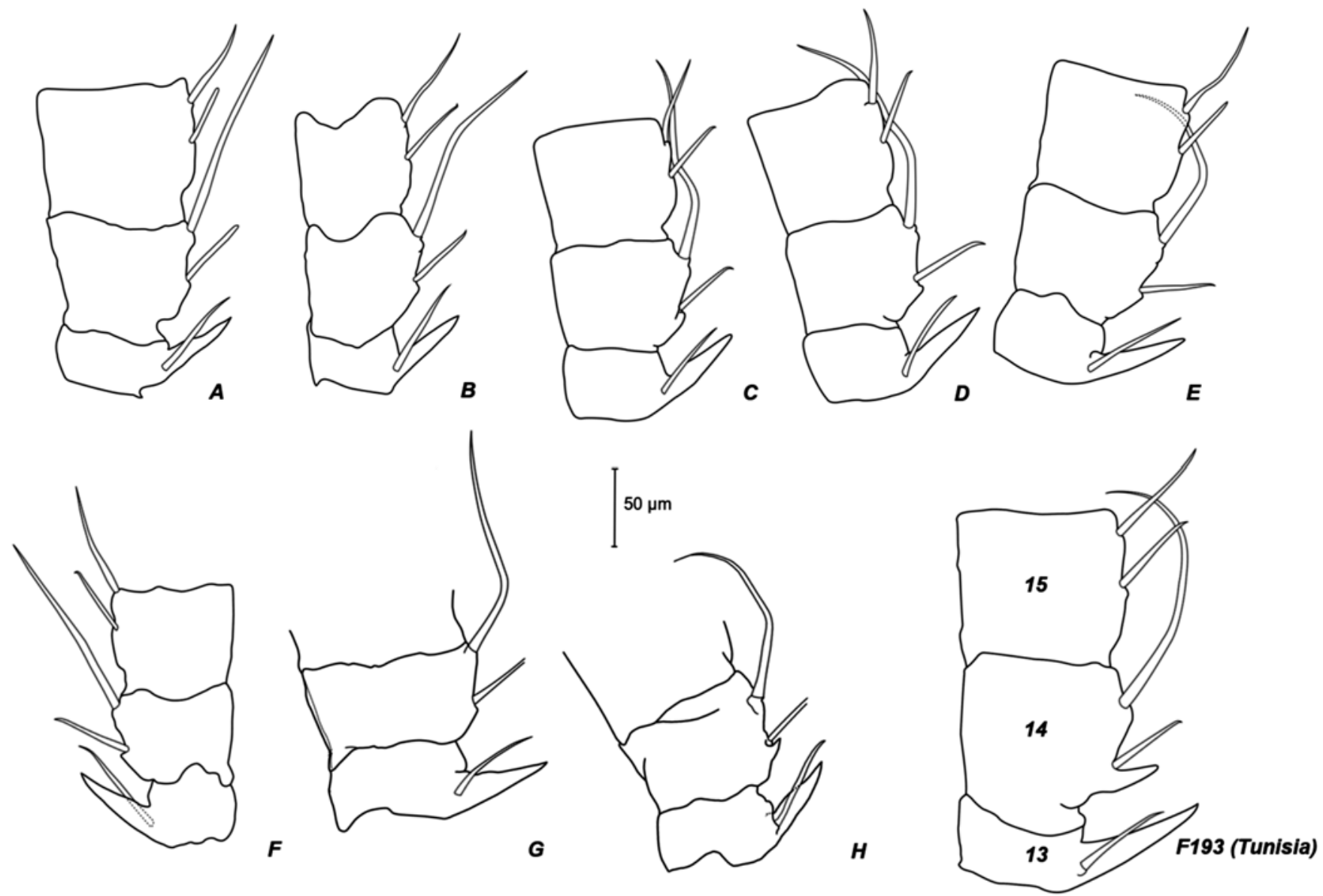

Fig. 3 - Segments 13-15 of the right male antennule from Malta. A-H) compared with an individual from Tunisia (site F193). A, B, F) MT002; C, D, E, G, H) MT001. / Segmenti $13^{\circ}-15^{\circ}$ delle antennule destre dei maschi maltesi. A-H) confrontati con un individuo tunisino (sito F193). A, B, F) MT002; C, D, E, G, H) MT001.

\section{DISCUSSION AND CONCLUSIONS}

Arctodiaptomus Kiefer, 1932 is a diverse diaptomid genus currently divided in various subgenera of doubtful validity (e.g. Ranga-Reddy, 1994; Dussart \& Defaye, 2002; Boxshall \& Halsey, 2004). Its type species, Arctodiaptomus wierzejskii, is a euryecious taxon, which can produce both subitaneous and drought-resistant eggs, and is able to colonise a wide range of different habitat types, ranging from brackish, warm and shallow temporary pools, to tundra pools and large oligotrophic lakes (Gurney, 1931; Kiefer, 1978; Ranga-Reddy, 1994; Błędzki \& Rybak, 2016). The species is widely distributed across the Palearctic region including the Maghreb, the whole Europe north to to the Shetlands, and the eastern Palearctic east to Mongolia and northern China (Dussart \& Defaye, 2002; Błędzki \& Rybak, 2016; Marrone et al., 2017). Oddly enough, although the species is known to occur in peninsular Italy and Sardinia, with few scattered populations (Ruffo \& Stoch, 2006), it seems to be absent in Sicily (Marrone et al., 2006). Conversely, in some relatively close areas, for example the Apulian peninsula, it is the most widespread calanoid copepod in temporary inland waters (Alfonso \& Belmonte, 2011), often dominating and characterizing the microcrustacean communities of these ponds (Alfonso et al., 2016).
The existence of morphological differences between different A. wierzejskii populations was already reported in literature; e.g. in the Tunisian, Algerian and Central Asian populations females have the right lobe of the fifth thoracic somite distinctly facing outwards (Gurney, 1931), the males of some Scottish populations present a projection of the antepenultimate segment of the right antennula much shorter than usual (Fryer \& Joyce, 1981), and an unusual male and female chaetotaxy was observed in Arctodiaptomus cf. wierzejskii from Mongolia (Marrone et al., 2015). Accordingly, in spite of the slight morphological difference pertaining to male right $\mathrm{A} 1$, we are here conservatively attributing the Maltese Arctodiaptomus populations to A. wierzejskii. However, also in the light of the wide distribution area and the great variety of habitats colonized by the species, it cannot be excluded that under the binomen Arctodiaptomus wierzejskii are actually lumped several different evolutionary lineages. The molecular characterization of selected populations is needed in order to understand whether the observed morphological differences are consistent with a clear pattern of genetic diversity, or are rather to be ascribed to a noteworthy intraspecific morphological variability with no taxonomical value. 
To date no information on the presence of calanoid copepods in Maltese inland waters was available. The present finding thus constitutes the first record of a representative of the family Diaptomidae in the Maltese Archipelago, and contributes to the knowledge of the distribution of freshwater calanoids in the Mediterranean area. However, the finding of an unidentified calanoid specimen in a rock pool in the area of Ghallis (Malta; S. Lanfranco, in litteris) suggests that diaptomids could be widespread in the Maltese Archipelago, and that more surveys aimed at getting a better knowledge of its freshwater copepod fauna are desirable.

\section{Acknowledgements}

Sandro Lanfranco (University of Malta, Malta) is warmly acknowledged for having shared the unpublished information about the finding of an unidentified diaptomid copepod in the area of Ghallis. Salvo Napoli and Federica Vicari provided support in the frame of the field and laboratory work. Valentina Pieri kindly identified the ostracods. D.M.P. Galassi (Università degli Studi dell'Aquila, Italy) and an anonymous reviewer are kindly acknowledged for their comments on the first draft of the manuscript.

\section{REFERENCES}

Alfonso G. \& Belmonte G., 2011 - Calanoida (Crustacea Copepoda) from the inland waters of Apulia (southeastern Italy). Journal of Limnology, 70 (1): 57-68. $<$ doi: 10.3274/JL11-70-1-08>

Alfonso G., Beccarisi L., Pieri V., Frassanito A. \& Belmonte G., 2016 - Using crustaceans to identify different pond types. A case study from the Alta Murgia National Park, Apulia (South- eastern Italy). Hydrobiologia, 782 (1): 53-69. <doi: 10.1007/s10750-0162669-y>

Alonso M., 1996 - Crustacea, Branchiopoda. In: Fauna Iberica. Ramos M. A. et al. (eds.). Vol. 7. Museo Nacional de Ciencias Naturales, Consejo Superior de Investigaciones Cientificas, Madrid.

Baldacchino A. E., 1983 - A preliminary list of freshwater crustaceans from the Maltese Islands. The Central Mediterranean Naturalist, 1 (2): 49-50.

Błędzki L. A. \& Rybak J. I., 2016 - Freshwater crustacean zooplankton of Europe. Springer, Switzerland. <doi: 10.1007/978-3-319-29871-9>

Boxshall G. A. \& Halsey S. H., 2004 - An Introduction to copepod diversity. Vol. I. The Ray Society, London.

Damian-Georgescu A., 1966 - Calanoida (Forme de apădulce). Fauna R.S.R. Crustacea, Copepoda. Editura Academiei RSR, Bucharest. [in Romanian].

Deidun A., Sciberras A., Formosa J., Zava B., Insacco G., Corsini-Foka M. \& Crandall K. A., 2018 - Invasion by non-indigenous freshwater decapods of Malta and Sicily, central Mediterranean Sea. Journal of Crustacean Biology, 38 (6): 748-753. < doi: 10.1093/jcbiol/ ruy076>

Dussart B. \& Defaye D., 2002 - World directory of Crustacea Copepoda of inland waters. I. Calaniformes. Backuhys Publishers, Leiden.
Einsle U., 1993 - Crustacea Copepoda. Calanoida und Cyclopoida. Süsswasserfauna Mitteleuropas, 8/4-1. Gustav Fisher Verlag, Stuttgart.

Fryer G. \& Joyce A., 1981 - The Distribution of Some Freshwater Copepods and its Bearing on the History of the Fauna and Flora of the British Isles. Journal of Biogeography, 8 (4): 281-291. <doi: 10.2307/2844763>

Gurney R., 1931 - British fresh-water Copepoda. The Ray Society, London.

Hupało K., Stoch F., Karaouzas I., Wysocka A., Rewicz T., Mamos T. \& Grabowski M., 2019 - Freshwater Malacostraca of the Mediterranean Islands. Diversity, origin and conservation perspectives In: Freshwater Crustacean Conservation. Crustacean Issues. CRC Press, Taylor and Francis Group.

Kiefer F., 1978 - Das Zooplankton der Binnengewässer. Freilebende Copepoda. Die Binnengewässer. Schweiz erbart'scheVerlagbuchhandlung E., Stuttgart: 26 (2): 1-343.

Korn M., Marrone F., Pérez-Bote J. L., Machado M., Cristo M., Da Fonseca L. C. \& Hundsdoerfer A. K., 2006 - Sister species within the Triops cancriformis lineage (Crustacea, Notostraca). Zoologica Scripta, 35: 301322. <doi: 10.1111/j.1463-6409.2006.00230.x>

Lanfranco S., 2001 - A review of the branchiopod fauna of the Maltese Islands (Crustacea: Branchiopoda). The Central Mediterranean Naturalist, 3 (3): 109-114.

Lanfranco S., De Walsche C., Schembri P. J. \& Mertens J., 1991 - Branchiopods (non-cladocerans) of the Maltese Islands (Central Mediterranean). Hydrobiologia, 212: 241-243.

Lukić D., Waterkeyn A., Rabet N., Mioduchowska M., Geudens B., Vanschoenwinkel B., Brendonck L. \& Pinceel T., 2019 - High genetic variation and phylogeographic relations among Palearctic fairy shrimp populations reflect persistence in multiple southern refugia during Pleistocene ice ages and postglacial colonisation. Freshwater Biology, 64: 1896-1907. $<$ doi: 10.1111/fwb.13380>

Marrone F., Castelli G., Barone R. \& Naselli-Flores L., 2006 - Ecology and distribution of Calanoid Copepods in Sicilian inland waters (Italy). Verhandlungen des Internationalen Verein Limnologie, 29: 21502156.

Marrone F., Alonso M., Pieri V., Augugliaro C. \& Stoch F., 2015 - The crustacean fauna of Bayan Onjuul area (Tôv Province, Mongolia) (Crustacea: Branchiopoda, Copepoda, Ostracoda). North-Western Journal of Zoology, 11 (2): 288-295.

Marrone F., Korn M., Stoch F., Naselli-Flores L. \& Turki S., 2016 - Updated checklist and distribution of large branchiopods (Branchiopoda: Anostraca, Notostraca, Spinicaudata) in Tunisia. Biogeographia - The Journal of Integrative Biogeography, 31: 27-53. <doi: 10.21426/B631132736>

Marrone F., Alfonso G., Naselli-Flores L. \& Stoch. F., 2017 - Diversity patterns and biogeography of Diaptomidae (Copepoda, Calanoida) in the Western Palearctic. Hydrobiologia, 800: 45-60. <doi: 10.1007/ s10750-017-3216-1> 
Marrone F. \& Vecchioni L., 2020 - The genus Daphnia in Sicily and Malta (Crustacea, Branchiopoda, Anomopoda). In: Life On Islands. Biodiversity in Sicily And Surrounding Islands. La Mantia T. (ed.). Studies dedicated to Bruno Massa.

Meisch C., 2000 - Freshwater Ostracoda of Western and Central Europe; Spektrum Akademischer Verlag Gm$b H$, Heidelberg/Berlin, Germany.

Petkovski T. K., 1983 - Calanoides - Calanoida (Crustacea - Copepoda). Faune de Macedonie, 5. Musée Histoire Naturelle de Macedonie, Skopje.

Ranga-Reddy Y., 1994 - Copepoda: Calanoida: Diaptomidae. Key to the genera Heliodiaptomus, Allodiaptomus, Neodiaptomus, Phyllodiaptomus, Eodiaptomus, Arctodiaptomus and Sinodiaptomus. Guides to the Identification of the Microinvertebrates of the Continental Waters of the World. SPB Academic Publishing, The Hague.

Ruffo S. \& Stoch F., 2006 - Checklist and distribution of the Italian fauna. Memorie del Museo Civico di Storia Naturale di Verona, Sezione Scienze della Vita, 17, 2 Serie.

Schembri P. J., 1993 - Physical geography and ecology of the Maltese Islands: A brief overview. In: Malta: Food, agriculture, fisheries and the environment Busuttil S., Lerin F. \& Mizzi, L., (eds.). CIHEAM-IAMM Options Méditerranéennes: Série B. Etudes et Recherches, Montpellier, 7: 27-39.

Stella E., 1984 - Crustacea. Copepoda: Calanoida. Fauna d'Italia XXI. Edizioni Calderini, Bologna.

Vecchioni L., Deidun A., Sciberras J., Sciberras A., Marrone F. \& Arculeo M., 2017 - The late Pleistocene origin of the Italian and Maltese populations of Potamon fluviatile (Malacostraca: Decapoda): insights from an expanded sampling of molecular data. The European Zoological Journal, 84 (1): 575-582. < doi: 10.1080/24750263.2017.1405084>

Vecchioni L., Marrone F., Deidun A., Adepo-Gourene B., Froglia C., Sciberras A., Bariche M., Çiçek Burak A., Foka-Corsini M. \& Arculeo M., 2019 - DNA Taxonomy Confirms the Identity of the Widely-Disjunct Mediterranean and Atlantic Populations of the Tufted Ghost Crab Ocypode cursor (Crustacea: Decapoda: Ocypodidae). Zoological Science, 36 (4): 322-329. <doi: 10.2108/zs180191> 